\title{
ANALISIS MODEL MENTAL SISWA DALAM PENGGUNAAN UNIT KEGIATAN BELAJAR MANDIRI TENTANG HIDROKARBON
}

\author{
Vicky Enggy Clovidea Indra Eky ${ }^{1}$, Nyoman Tika ${ }^{2}$, I Wayan Muderawan ${ }^{3}$ \\ 1,2,3 Universitas Pendidikan Ganesha \\ Singaraja, Indonesia \\ e-mail: rzrmost@hotmail.com ${ }^{1}$, nyomanntika@yahoo.ac.id², \\ i.wayan.muderawan@undiksha.ac.id ${ }^{3}$
}

\begin{abstract}
Abstrak
Penelitian ini merupakan penelitian kuantitatif yang bertujuan untuk mendeskripsikan model mental siswa tentang konsep-konsep hidrokarbon setelah dibelajarkan melalui penggunaan UKBM di SMA Negeri Bali Mandara. Penelitian ini dilakukan dengan teknik survei, melibatkan 82 orang siswa. Pengumpulan data dilakukan dengan pemberian tes model mental dua tingkat (two-tier) dengan menggabungkan pilihan ganda dan tes uraian pada materi kimia kelas XI Kurikulum 2013. Analisis data berupa persentase jawaban siswa yang dikategorikan ke dalam empat tipe model mental yakni model mental ilmiah dan model mental alternatif (benar sebagian, miskonsepsi khusus, dan tidak ada tanggapan). Hasil penelitian ini menunjukkan, bahwa model mental siswa tentang konsep-konsep hidrokarbon setelah dibelajarkan melalui penggunaan UKBM di SMA Negeri Bali Mandara adalah 7,32\% model mental ilmiah dan $92,69 \%$ model mental alternatif, yang terdiri atas $39,94 \%$ model mental benar sebagian, 35,37\% model mental miskonepsi khusus, dan $17,38 \%$ tidak ada tanggapan. Hasil data tersebut menunjukkan bahwa sebagian besar siswa mengalami model mental alternatif karena tidak memiliki pemahaman terkait representasi ketiga level kimia dan interkoneksinya tentang materi hidrokarbon.
\end{abstract}

Kata kunci: Analisis, Model Mental Siswa, Senyawa Hidrokarbon, UKBM, SMA Negeri Bali Mandara.

\begin{abstract}
This research was quantitative research that aimed to describe student mental model about hydrocarbon concepts after being learned through the use of UKBM at SMA Bali Mandara. The research used survey technique, which 82 students as subject. The data collected through two-tier mental model test by combining multiple choices and description tests on chemistry matter in class XI Curriculum 2013. Analysis of existing data of students categorized in mental models type namely scientifically correct mental model and alternative mental model (partially correct, specific misconceptions, and no response). The results of this study indicate that the student mental model about the hydrocarbons concepts after learning from the use of UKBM at Bali Mandara High School was $7.32 \%$ scientifically correct mental model and $92.69 \%$ alternative mental model, consisting of $39.94 \%$ partially correct mental model, $35.37 \%$ specific
\end{abstract}


misconception mental model, and $17.38 \%$ no responses. Data results indicate that most students had experience alternative mental models because they do not have an understanding of the representation of the three chemical and interconnected levels of hydrocarbon matter.

Keywords: Analysis, Bali Mandara High School, Hydrocarbon Compound, Student's Mental Model UKBM

\section{PENDAHULUAN}

Proses pembelajaran di sekolah pada kurikulum 2013 diatur dalam Permendikbud No.22 Tahun 2016 tentang standar proses pendidikan dasar dan menengah. Standar proses adalah kriteria mengenai pelaksanaan pembelajaran pada satuan pendidikan untuk mencapai Standar Kompetensi Lulusan. Pada standar proses diatur mengenai pengelolaan pembelajaran yang mencakup perencanaan proses pembelajaran, pelaksanaan proses pembelajaran, penilaian hasil pembelajaran, dan pengawasan proses pembelajaran. Perencanaan pembelajaran terdiri atas pembuatan silabus dan Rencana Pelaksanaan Pembelajaran (RPP). Pada pembuatan RPP seorang guru seharusnya memerhatikan karakteristik peserta didik agar proses pembelajaran berjalan dengan baik. Karakterisitik peserta didik dalam satu kelas tentu berbeda sehingga dalam satu kelas guru harus melayani peserta didik yang memiliki kemampuan atau potensi akademik berbeda. Oleh karena itu, Direktorat Pembinaan SMA menerbitkan panduan pengembangan Unit Kegiatan Belajar Mandiri (UKBM) untuk mengatasi kesulitan dalam proses pembelajaran. UKBM ini dikembangkan di sekolah-sekolah yang menerapkan kurikulum 2013 dengan Sistem Kredit Semester (SKS). Namun, saat ini UKBM belum banyak digunakan di sekolah-sekolah.

UKBM merupakan satuan pelajaran yang disusun secara berurutan dari mudah sampai sukar. UKBM digunakan sebagai perangkat belajar bagi peserta didik untuk mencapai kompetensi pengetahuan dan keterampilan. Isi UKBM mengutamakan pemberian stimulus belajar yang memungkinkan tumbuhnya kemandirian dan pengalaman peserta didik untuk terlibat aktif dalam penguasaan kompetensi secara utuh melalui pembelajaran berpusat pada peserta didik (student active) yang mendorong kemampuan berpikir tingkat tinggi (Higer Order Thinking Skills/HOTS), agar menumbuhkan penguasaan kecakapan hidup abad 21, seperti berpikir kritis, bertindak kreatif, bekerja sama, dan berkomunikasi, serta pembudayaan literasi, dan Penguatan Pendidikan Karakter (PPK) (Direkorat Pembinaan Sekolah Menengah Atas, 2017).

UKBM ini dapat digunakan pada semua bidang ilmu, salah satunya pada bidang ilmu kimia. IImu kimia merupakan cabang ilmu pengetahuan alam (IPA) yang mempelajari tentang struktur, sifat dan perubahan materi serta energi yang menyertainya (Whitten, et al., 2004). IImu kimia tersusun dari banyak konsep dan topik yang abstrak karena tidak kasat mata (Gabel, 1999; Johstone, 1993). Dalam mempelajari ilmu kimia harus memahami ketiga level representasi, yakni level makroskopis, submikroskopis, dan simbolik (Jansoon, Coll, \& Somsook, 2009). Menurut Chandrasegaran et al. (2007) level makroskopis menjelaskan tentang fenomena kimia yang dapat diamati, misalnya perubahan wujud, perubahan warna, terbentuknya endapan, dan lain-lain; level submikroskopis menjelaskan bagian kimia pada tingkat partikel yang tidak dapat dilihat oleh mata, level ini dapat menjelaskan susunan atom-atom, molekul, interaksi antar molekul pada sebuah senyawa dan suatu reaksi; level simbolik mencakup simbol-simbol yang digunakan pada atom, molekul, ion, struktur molekul, persamaan kimia, pemberian nama unsur dan senyawa, diagram fasa, mekanisme reaksi, dan lain-lain.

Pemahaman terhadap ketiga level representasi tersebut seringkali diistilahkan sebagai model mental. Menurut Wang (2007), model mental merupakan representasi intrinsik yang muncul pada proses kognitif berupa objek, dan gagasan untuk menjelaskan, menggambarkan, memprediksi atau memberikan alasan pada sebuah fenomena. Pemahaman terkait ketiga level kimia ini menjadi salah satu pelajaran yang sulit bagi siswa. Laliyo (2011) yang menyatakan bahwa pada umumnya siswa memiliki kesulitan dalam memahami dan menjelaskan konsep perubahan wujud pada level sub-mikroskopis. Bila siswa tidak dapat mengaitkan ketiga level representasi kimia maka konsep yang mereka pahami akan terpecah-pecah dan memungkinkan siswa hanya menghafal dikarenakan konsep yang dipelajari hanya sampai di permukaannya saja (Dalton, 2003). 
Salah satu sekolah di Bali yang menggunakan UKBM ialah SMA Negeri Bali Mandara. SMA Negeri Bali Mandara berlokasi di Desa Kubutambahan, Kecamatan Kubutambahan, Kabupaten Buleleng, Bali. SMA Negeri Bali Mandara merupakan sekolah yang menerapkan Kurikulum 2013 dengan sistem SKS. Berdasarkan studi pendahuluan yang peneliti lakukan di SMA Negeri Bali Mandara, diperoleh fakta bahwa sekolah tersebut sudah menggunakan UKBM selama setahun pada pembelajaran kimia. Salah satu materi kimia yang menggunakan UKBM ialah materi hidrokarbon.

Tujuan penelitian ini adalah untuk mendeskripsikan dan menjelaskan model mental siswa setelah dibelajarkan melalui penggunaan UKBM tentang hidrokarbon.

\section{METODE}

Penelitian ini dilaksanakan di SMA Negeri Bali Mandara pada semester ganjil tahun ajaran 2017/2018. Sampel dalam penelitian adalah siswa kelas XI MIPA sebanyak 82 orang. Penelitian dirancang mulai dari tahap: (1) penyusunan instrument, (2) validasi instrument, (3) uji coba instrument, (4) pengumpulan data, (5) analisis data hasil penelitian, serta (6) pelaporan. Instrumen yang digunakan dalam penelitian ini adalah tes model mental yang diadaptasi dari pengembangan oleh Suja (2018), berbentuk pilihan ganda dua tingkat (two-tier test), terdiri dari dua bagian, yaitu bagian pertama berisikan pilihan jawaban (level makroskopis) yang telah disediakan berkaitan dengan konten, sedangkan pada bagian kedua pelajar dituntut untuk memberikan alasan/argumentasi (level submikroskopis dan level simbolik) atas jawaban bagian pertama. Model mental siswa dikelompokkan berdasarkan kemiripan jawaban siswa ke dalam tipe model mental tertentu. Dalam penelitian ini, model mental dikelompokkan ke dalam empat tipe, yaitu: tidak ada jawaban/tanggapan (No Response/NR), miskonsepsi khusus pada bagian tertentu (Specific Misconceptions/SM), benar sebagian (Partially Correct/PC), dan benar secara ilmiah (Scientifically Correct/SC) (Sendur, dkk., 2010). Selanjutnya, tiga model mental pertama secara umum disebut sebagai model mental alternatif, sedangkan model mental keempat dilabel sebagai model ilmiah atau model konseptual.

\section{HASIL DAN PEMBAHASAN}

Data hasil tes dan profil model mental siswa kelas XI di SMA Negeri Bali Mandara tentang hidrokarbon setelah dibelajaran dengan penggunaan UKBM pada Tabel 1 menunjukkan, bahwa $7,32 \%$ konsep-konsep hidrokarbon dipahami oleh siswa dalam bentuk model mental ilmiah dan $92,69 \%$ dalam bentuk model mental alternatif. Model mental alternatif tersebut terdiri dari $39,94 \%$ model mental benar sebagian, 35,37\% model mental miskonsepsi khusus, dan 17,38\% tidak ada tanggapan. Data profil model mental siswa berdasarkan persentase masing-masing kategori model mentalnya dapat disajikan dalam bentuk diagram pie pada Gambar 1.

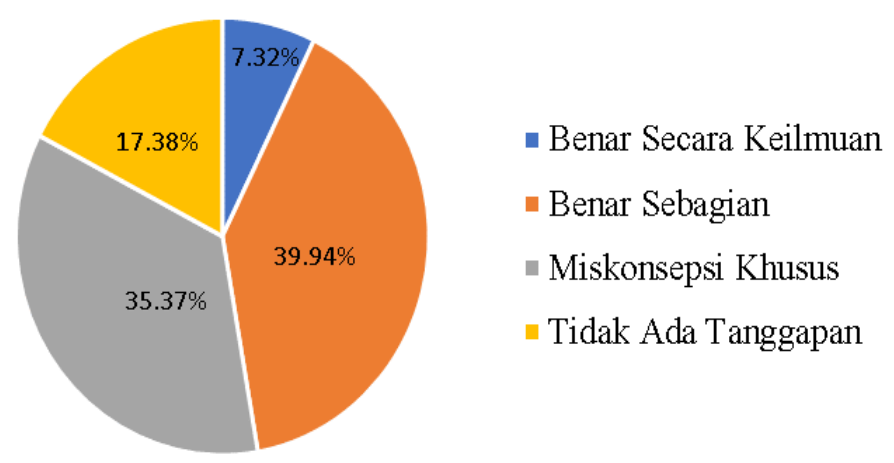

Gambar 1. Diagram Pie Profil Model Mental Siswa

Sebagian besar siswa memiliki model mental benar sebagian berkaitan dengan identifikasi senyawa hidrokarbon. Siswa dapat menjelaskan pembakaran hidrokarbon menghasilkan gas karbondioksida yang dapat mengeruhkan air kapur, tetapi tidak mampu menjelaskan apa yang terjadi pada tingkat partikel materi dan penulisan persamaan reaksinya. Secara konseptual pembakaran sempurna hidrokarbon menghasilkan gas karbon dioksida, ketika dialirkan menuju 
larutan $\mathrm{Ca}(\mathrm{OH}) 2$ maka akan bereaksi dan membentuk zat baru yakni $\mathrm{CaCO} 3$ yang menyebabkan larutan berubah menjadi keruh. Hasil ini sesuai dengan penelitian Pujiasih (2018) yang menyatakan bahwa siswa tidak mampu dalam menjelaskan level submikroskopis mengenai identifikasi unsur $\mathrm{C}, \mathrm{H}$, dan $\mathrm{O}$ dalam senyawa hidrokarbon

Pada indikator membandingkan titik didih isomer alkana sebagian besar siswa memiliki model mental miskonsepsi, yang menjelaskan bahwa alkana rantai bercabang memiliki titik didih yang lebih tinggi daripada rantai lurus dan tidak mampu menggambarkan interaksi antar molekul pada senyawa isomer alkana. Secara keilmuan alkana rantai lurus memiliki titik didih lebih tinggi dari pada alkana bercabang dikarenakan pada alkana rantai lurus memungkinkan untuk menata atom-atomnya sedemikian rupa sehingga sesuai dengan jari-jari van der Waals. Bentuk rantai lurus dan memanjang dapat membuat struktur alkana akan menjadi lebih rapat dan kompak. Hal ini menyebabkan tarikan van der Waals antar molekulnya menjadi maksimal (Suja, 2014).

Sedangkan, alkana rantai bercabang memiliki interaksi molekul yang lebih lemah. Temuan ini sejalan dengan penelitian Andhini (2010) yang menyatakan bahwa siswa tidak dapat menjelaskan fenomena level submikroskopis dan simbolik pada konsep isomer struktur dan titik didih senyawa alkana. Pada penelitian Suja (2015) menyatakan sebagian besar mahasiswa mengalami miskonsepsi dalam menjelaskan titik didih dan titik leleh senyawa

Pada indikator menentukan wujud senyawa hidrokarbon berdasarkan data titik leleh dan titik didihnya sebagian siswa memiliki model mental miskonsepsi, yang menyatakan bahwa 2-metil butana berwujud cair karena memiliki titik didih yang lebih rendah dibandingkan $n$-pentana pada suhu ruang tanpa penjelasan level submikroskopisnya. Secara konseptual, data yang terdapat pada soal, dapat dibuat bentuk grafik yang dapat menunjukkan wujud pada senyawa-senyawa pada soal tersebut. Pada grafik dapat diterangkan bahwa yang memiliki wujud cair pada suhu kamar 300C ialah $n$-pentana. Hal ini dikarenakan $n$-pentana memiliki titik didih sebesar $360 \mathrm{C}$, sedangkan 2-metil butana memiliki titih didih sebesar $280 \mathrm{C}$. Wujud alkana ini dapat dipengaruhi oleh ukuran massa molekul, bila semakin besar ukuran massa molekul sebuah alkana maka semakin kuat gaya tarik antar molekulnya yang mengakibatkan kerapatannya tinggi. Hasil penelitian ini sejalan dengan temuan Luoga et al. (2013) dan Pinarbasi et al. (2009) yang menunjukkan bahwa siswa mengalami miskonsepsi pada submateri kenaikan titik didih dan penurunan titik beku yang disebabkan oleh siswa tidak menguasai ketiga leve/ representasi kimia.

Pada indikator membandingkan kepolaran isomer cis-trans sebagian siswa dengan model mental miskonsepsi khusus menjawab keliru dengan memandang senyawa trans 1,2dibromoetena bersifat polar karena memiliki sisi atau struktur yang simetris. Secara konseptual pada senyawa cis dan trans yang memiliki kepolaran lebih tinggi adalah senyawa cis 1,2dibromoetena dikarenakan pada senyawa tersebut memiliki dua atom bromin yang berada pada satu sisi molekul. Sisi molekul ini akan memiliki kutub negatif, sedangkan sisi lainnya memiliki kutub positif sehingga momen dipol pada senyawa cis lebih dari nol, yang mengakibatkan senyawa tersebut bersifat polar. Sedangkan, pada senyawa trans, kutub negatif berada pada sisi yang bersilangan sehingga momen dipolnya sama dengan nol. Temuan ini sesuai dengan penelitian Unal et al. (2006) menemukan bahwa siswa mengalami kesulitan dalam menjelaskan level submikroskopis pada polaritas suatu molekul. Pada penelitian Suja et al. (2015) menemukan bahwa tidak ada mahasiswa yang menentukan polaritas senyawa berdasarkan momen dipolnya.

Pada indikator menentukan kelarutan senyawa hidrokarbon sebagian besar siswa memiliki model mental benar sebagian, yang dapat menentukan senyawa pada bagian lapisan tertentu, namun tidak memahami mengapa larutan tersebut dapat membentuk lapisan pada level submikroskopis. Pada penulisan struktur sebagian siswa tidak dapat menggambarkan sikloheksana dengan benar. Secara keilmuan campuran tersebut dapat membentuk dua lapisan disebabkan karena adanya perbedaan kepolaran yang mana sikloheksana bersifat nonpolar, sedangkan air bersifat polar yang berarti larutan ini tidak akan saling melarutkan. Posisi sikloheksana berada pada bagian atas karena sikloheksana memiliki massa jenis yang lebih kecil daripada air. Hasil penelitian ini sesuai dengan penelitian Suja (2015) yang menyatakan bahwa rendahnya pemahaman siswa dalam memprediksi kelarutan senyawa yang disebabkan ketidakmampuan siswa dalam menjelaskan fungsi struktur molekul terhadap sifat makroskopis senyawannya dan penelitian Abas (2013) yang menyatakan bahwa pemahaman siswa pada level submikroskopis masih rendah dibandingkan dengan level lainnya pada materi kelarutan zat.

Pada indikator menentukan hasil reaksi adisi senyawa alkena sebagian besar siswa memiliki model mental benar sebagian, yang menjelaskan reaksi adisi pada senyawa alkena dan hasil reaksi alkena dengan brom yang dapat menghilangkan warna dari larutan brom tersebut, namun siswa tidak dapat menjelaskan mengapa reaksi tersebut dapat terjadi pada tingkat partikel materi. Secara konseptual, reaksi adisi terjadi apabila terdapat ikatan rangkap. Larutan brom 
dalam $\mathrm{CCl} 4$ yang awal berwarna jingga ketika larutan ini ditambahkan tetes demi tetes ke dalam propena warna pada larutan brom tersebut akan menjadi tidak berwarna disebabkan terbentuknya senyawa dibromida yang tidak berwarna. Pada penjelasan tingkat submikroskopis molekul Br2 mendekati molekul propena, awan elektron pada ikatan rangkap propena menyebabkan molekul $\mathrm{Br} 2$ terpolarisasi, sehingga pasangan elektronya bergeser menuju salah satu atom brom. Bagian positif molekul brom yang terpolarisasi ditarik mendekati awan elektron tersebut sehingga terbentuk kompleks yang tidak stabil diikuti dengan terjadinya pelepasan ion bromida. Ion bromida yang terbentuk selanjutnya menyerang ion bromonium dari arah berlawanan, sehingga dihasilkan senyawa dibromida. Hasil penelitian ini sejalan dengan penelitian Pujiasih (2018) yang menyatakan bahwa siswa belum mampu menjelaskan mengapa warna brom hilang ketika direaksikan dengan propena pada level submikroskopis.

Pada indikator membandingkan kestablian senyawa cis dan trans sebagian besar siswa memiliki model mental miskonsepsi, yang menjelaskan cis lebih stabil daripada trans. Secara submikroskopis siswa memandang posisi gugus metil mempengaruhi kestabilan, akan tetapi siswa tidak mampu menjelaskan gaya tolak-menolak yang terjadi antara gugus tersebut. Secara konseptual pada senyawa cis dan trans yang memiliki kestabilan lebih tinggi ialah senyawa trans dikarenakan senyawa tersebut memiliki dua gugus metil pada sisi berseberangan, sehingga gaya tolak menolaknya rendah. Pada struktur cis terdapat gugus metil berdekatan sehingga gaya tolakmenolaknya besar, hal ini menyebabkan senyawa cis kurang stabil. Hasil penelitian ini sejalan dengan penelitian Sucitra et al. (2016) yang menyatakan bahwa siswa mengalami miskonsepsi dalam menentukan dan menjelaskan kestabilan pada isomer geometri (cis-trans). Hasil penelitian lain yakni penelitian Suja et al. (2015) menyatakan mahasiswa mengalami miskonsepsi berkaitan dengan kestabilan isomer cis/trans 1,3-dimetilsikloheksana.

Berdasarkan pemaparan diatas model mental siswa setelah dibelajarkan melalui penggunaan UKBM mengenai konsep hidrokarbon sebagian besar tergolong model mental alternatif, dengan persentase sebesar $92,69 \%$ yang tergolong model mental benar sebagian (PC) dan model mental miskonsepsi khusus. Temuan penlitian ini sejalan dengan hasil penelitian Pujiasih (2018), Yoni (2017), Sucitra (2016), Suja (2015), dan Okvasari (2014) bahwa model mental pebelajar sebagian besar tergolong model mental alternatif karena ketidakpahaman mereka tentan level submikroskopis kimia.

\section{SIMPULAN DAN SARAN}

Berdasarkan hasil penelitian dan pembahasan di depan dapat disimpulkan, bahwa profil model mental siswa kelas XI SMA Negeri Bali Mandara tentang konsep-konsep hidrokarbon setelah dibelajarkan melalui penggunaan UKBM sebanyak 7,32\% siswa mengalami model mental ilmiah dan 92,69\% siswa mengalami model mental alternatif, yang meliputi 39,94\% model mental benar sebagian, 35,37\% model mental miskonsepsi khusus, dan 17,38\% tidak ada tanggapan. Data tersebut menunjukkan sebagian besar siswa mengalami model mental alternatif karena tidak memiliki pemahaman terkait representasi ketiga level kimia dan interkoneksinya tentang materi hidrokarbon.

\section{DAFTAR RUJUKAN}

Abas, N. 2013. Kajian Representasi Sub-Mikroskopik Siswa Tentang Konsep Kelarutan Zat. Jurnal Jurusan Pendidikan Kimia Fakultas Matematika dan IPA Universitas Negeri Gorontalo.

Andari, M. 2012. Analisis Profil Model Mental Siswa SMA dan Faktor-faktor yang Mempengaruhi pada Topik Larutan Penyangga. Tesis Universitas Pendidikan Indonesia: Bandung. (diakses tanggal 25 Februari 2018).

Andhini, R. 2010. Profil Model Mental Siswa Pada Pokok Bahasan Senyawa Hidrokarbon. Bandung: UPI.

Arikunto, S. 2005. Dasar-Dasar Evaluasi Pendidikan. Jakarta: PT Bumi Aksara.

Arviani, V. 2011. Identifikasi Pemahaman Konsep Laju Reaksi Siswa Kelas XI SMA Brawijaya Smart Schoo. http://karya-ilmiah.um.ac.id (diakses tanggal 25 Februari 2018).

BSNP. 2006. Panduan Penyusunan Kurikulum Tingkat Satuan Pendidikan Jenjang Pendidikan Dasar dan Menengah. Jakarta: BSNP. 
Chandrasegaran, A.L., David F. Treagust, \& M. Moecerino. An Evaluation of a Teaching Intervention to Promote Students' Ability to Use Multiple Levels of Representation When Describing and Explaining Chemical Reactions. Journal Research Science Education. 38: 237-248. Tersedia pada https://www.researchgate.net (diakses tanggal 25 Februari 2018).

Chang, R. 2005. Kimia Dasar Konsep-Konsep Inti Edisi ketiga Jilid 1. Jakarta: Erlangga.

Chang, R. 2005. Kimia Dasar Konsep-Konsep Inti Edisi ketiga Jilid 2. Jakarta: Erlangga.

Devetak, I., Lorber, E. D., Jurisevic, M., Glazar, S. A. 2009. Comparing Slovenian year 8 and year 9 elementary school pupils' knowledge of electrolyte chemistry and their intrinsic motivation. Journal Chemistry Education Research and Practice. 10: 281-290. Tersedia pada http://www2.pef.uni-lj.si (diakses tanggal 25 Februari 2018).

Direktorat Pembinaan SMA. 2017. Panduan Pengembangan Unit Kegiatan Belajar Mandiri (UKBM). Jakarta: Kemendikbud.

Eckberg, C.; Zemmer, J.; Reeves, J.; \& Ward, C. 1994. An Intermolecular Forces Study using IBMPSL. Journal of Chemical Education, 71(9) A225-A237.

Handayanti, Y., Setiabudi, A., Nahadi. 2015. Analisis Profil Model Mental Siswa SMA pada Materi Laju Reaksi. Jurnal Penelitian dan Pembelajaran IPA. 1(1): 107-122. Tersedia pada http://repository.upi.edu (diakses tanggal 25 Februari 2018).

Harrison, A. G. \& Treagust, D. F. 1999. Learning about Atoms, Molecules, and Chemical Bonds: A Case Study of Multiple-Model Use in Grade 11 Chemistry. Article Science Education. Tersedia pada https://www.researchgate.net (diakses tanggal 25 Februari 2018).

Jansoon, N., Richard K. Coll, \& Ekasith Somsook. 2009. Understanding

Mental Models of Dilution in That Students. International Journal of Environmental \& Science Education, 4(2): 147-168. Tersedia pada http://files.eric.ed.gov (diakses tanggal 25 Februari 2018).

Johnstone, A. H. 1991. Why is Science Difficult to Learn? Things are Seldom What They Seem. Journal of Computer Assisted Learning, 7: 75-83. Tersedia pada https://www.researchgate.net (diakses tanggal 25 Februari 2018).

Johnstone, A.H. 2006. Chemical Education Research in Glasgow in Perspective. Chemistry Education and Practice. Vol. 7(2): 49-63. Tersedia pada https://pdfs.semanticscholar.org (diakses tanggal tanggal 30 Mei 2017).

Laliyo, L. A. R. 2011. Model Mental Siswa dalam Memahami Perubahan Wujud Zat. Jurnal Penelitian dan Pendidikan. Vol. 8, No. 1 (hlm 1-10). Tersedia pada http://repository.ung.ac.id (diakses tanggal 25 Februari 2018).

Luoga, N. E., Ndunguru, P. A., Mkoma, S.L. 2013. High School Students' Misconceptions About Colligative Properties In Chemistry. Tanzania Journal of Natural \& Applied Sciences. 4(1): 575-581

Moore, S.M. \& Victorsen, K. 2007. Developing the Conceptual Groundwork Needed to Understand Molecular Motion. lowa Science Teachers Journal, 34(2):13-17.

Okyasari, R. 2014. Profil Model Mental Siswa SMA pada Materi Sistem Koloid. Skripsi (tidak diterbitkan). Jurusan Pendidikan Kimia, Universitas Pendidikan Indonesia. Tersedia pada http://repository.upi.edu (diakses tanggal 25 Februari 2018).

Park, E. J. 2006. Student Perception and Conceptual Development as Represented by Student Mental Models of Atomic Structure. Dissertation Presented in Partial Fulfillment of the Requirements for the Degree Doctor of Philosophy in the Graduate School of The Ohio State University. Tersedia pada http://etd.ohiolink.edu (diakses tanggal tanggal 25 Februari 2018).

Pinarbasi, T., Sozbilir, M., Canpolat, N. 2009. Prospecitve Chemistry Teachers' Misconception About Colligative Properties: Boiling Point Elevation and Freezzing Point Depression. Chemistry Education Reasearch and Practioce. 10: 273-280 
Rahayu, S. \& Purwanto, J. 2013. Identifikasi Model Mental Siswa SMA Kelas X pada Materi Hukum Newton tentang Gerak. Jurnal UIN Sunan Kalijaga Yogyakarta. Vol. IX, No. 3 (hlm. 12-20). Tersedia pada http://digilib.uin-suka.ac.id (diakses tanggal 25 Februari 2018).

Sendur, G., Toprak, M., Pekmez, E. S. 2010. Analyzing of Students' Misconceptions About Chemical Equilibrium. Paper on International Conference on New Trends in Education and Their Implications. Antalya-Turkey. Tersedia pada http://conference.pixel-online.net. (diakses tanggal 25 Februari 2018).

Sudijono, Anas. 2011. Pengantar Evaluasi Pendidikan. Jakarta: Rajawali Pers.

Sugiyono. 2014. Metode Penelitian Kuantitatif, Kualitatif, dan R \& D. Bandung: Alfabet.

Suja, I W. 2015. Model Mental Mahasiswa Calon Guru Kimia dalam Memahami Bahan Kajian Stereokimia. Jurnal Pendidikan Indonesia. Vol. 4, No.2 (hlm. 625-638). Tersedia pada http://ejournal.undiksha.ac.id (diakses tanggal 25 Februari 2018).

Sukardi. 2010. Evaluasi Pendidikan: Prinsip dan Operasionalnya. Jakarta: Bumi Aksara.

Sukiman. 2012. Pengembangan Sistem Evaluasi. Yogyakarta: Insan Madani.

Suparsom, Sakri. 2015. Grade 12 Students' Conceptual Understanding and Mental Models of Galvanic Cells Before and After Leraning By Using Small-Scale Experiments in Conjunction with A Model Kit. Chemistry Education Research and Practice 16: 393-407

Unal, S. , Calik, M, Ayas, A. and Coll R.K. (2006) A Review of Chemical Bonding Studies: Needs, Aims, Methids of Exploring Students' Conceptions, General Knowledge Claims and Studenst' Alternative Conceptions, Research in Science and Technological Education , 24, 141-172.

Wang, Ch. Y. 2007. The Role of Mental-Modeling Ability, Content Knowledge, and Mental Models in General Chemistry Students' Understanding about Molecular Polarity. A Dissertation presented to the Faculty of the Graduate School University of Missouri Columbia. Tersedia pada https://mospace.umsystem.edu (diakses tanggal 25 Februari 2018).

Whitten, K.W., Raymond E. Davis, Larry Peck, \& George G, Stanley. 2004. General Chemistry Seventh Edition. Amerika: Brooks Cole.

Wiji., Liliasari., Sopandi, W., Muhammad, A. K. 2014. Kemampuan Berpikir Logis dan Model Mental Kimia Sekolah Mahasiswa Calon Guru. Jurnal Cakrawala Pendidikan. 33(1): 147156. Tersedia pada http://repository.upi.edu (diakses tanggal 25 Februari 2018). 